\title{
Changes in foliar litter decomposition of woody plants with elevation across an alpine forest-tundra ecotone in eastern Tibet Plateau
}

\author{
Yang Liu • Yamei Chen · Jian Zhang • Wanqin Yang • \\ Zhu Peng $\cdot$ Xinhua He $\cdot$ Changchun Deng $\cdot$ Runlian He
}

Received: 6 July 2015/Accepted: 25 March 2016/Published online: 9 April 2016

(C) The Author(s) 2016. This article is published with open access at Springerlink.com

\begin{abstract}
To determine litter decomposition rates at different elevations in the alpine forest-tundra ecotone under climate change scenarios in which woody plants shift their ranges upward, litterbags containing foliar litter were incubated on the surface of forest, tree line, and alpine meadow soils (3900, 4000, and $4200 \mathrm{~m}$ above sea level, respectively) in the eastern Tibet Plateau of China in October 2012. The selected woody plant species were Abies faxoniana, Betula albosinensis, Sorbus rufopilosa, Rhododendron taliense,
\end{abstract}

Communicated by Karen Harper.

Y. Liu · Y. Chen · J. Zhang · W. Yang $(\bowtie)$.

Z. Peng $\cdot$ C. Deng $\cdot$ R. He

Long-term Research Station of Alpine Forest Ecosystems, Institute of Ecology and Forestry, Sichuan Agricultural University, 211 Huimin Road, Wenjiang District,

Chengdu 611130, China

e-mail: ywq918@yahoo.com

Y. Liu · J. Zhang $\cdot$ W. Yang

Collaborative Innovation Center of Ecological Security in the Upper Reaches of Yangtze River, Chengdu 611130, China

X. He

Centre of Excellence for Soil Biology, College of

Resources and Environment, Southwest University,

Chongqing 400715, China

X. He

School of Plant Biology, University of Western Australia, Crawley 6009, Australia
Lonicera lanceolata, and L. myrtillus. Mass loss, carbon $(\mathrm{C})$, nitrogen $(\mathrm{N})$, and phosphorus $(\mathrm{P})$ release, and cellulose and lignin degradation in litter were examined from retrieved litterbags over a 6 month period at the end of one snow-covered season. The results showed that the mass loss of A. faxoniana, $L$. lanceolata, and $S$. rufopilosa litter, but not that of the other species, was accelerated at higher elevations. Abies faxoniana, B. albosinensis, and S. rufopilosa C release, A. faxoniana and $S$. rufopilosa $\mathrm{N}$ release, $L$. myrtillus, L. lanceolata, and $S$. rufopilosa $\mathrm{P}$ release, $B$. albosinensis, $S$. rufopilosa, and $R$. taliense cellulose degradation, and L. myrtillus lignin degradation significantly increased with increasing elevation. These results imply that changes in foliar litter decomposition with elevation, although species-specific, could indicate a possible shift in woody plant composition in the alpine forest-tundra ecotone under climate change scenarios. Thus, further studies regarding how elevation shifts could alter litter decomposition and ecosystem sustainability are warranted.

Keywords Alpine forest-tundra ecotone $\cdot$ Climate change - Elevation · Litter decomposition · Woody plants

\section{Introduction}

Global warming has strong impacts on high-elevation ecosystems (Stocker et al. 2013), as it leads to upward 
shifts of alpine plants (Pauli et al. 2007; Lenoir et al. 2008), as well as the tree line (Theurillat and Guisan 2001; Grace et al. 2002; Wipf and Rixen 2010). For example, graminoids and herbs have been gradually replaced by shrubs in alpine ecosystems (Cornelissen et al. 2007; Baptist et al. 2010), leading to alterations of plant community structure and species composition (Lenoir et al. 2008), as well as plant litter decomposition (Gavazov 2010).

The process of litter decomposition is controlled by environmental conditions, litter quality, and soil organisms (Berg and McClaugherty 2008). Climate change will directly alter environmental factors, such as soil temperature and moisture, snow cover, and soil freezing depth, which in turn affect litter decomposition (Sturm et al. 2005). Additionally, it will alter plant species composition and community structure, leading to changes in plant litter quality and nutrient cycling (Gavazov 2010). For example, shifts in plant communities could affect nutrient release (Santonja et al. 2015). However, whether this process could slow or accelerate litter decomposition is still uncertain.

Litter decomposition in alpine ecosystems is generally determined by low-temperature conditions (Baptist et al. 2010; Gavazov 2010). The pattern of foliar litter decomposition and its related releases of carbon (C) and nutrients at high elevations and latitudes are complicated during the long, snowcovered season (Baptist et al. 2010). It has been demonstrated that the first-year decomposition largely accounts for litter decomposition in subalpine forests in winter (Wu et al. 2010; Zhu et al. 2012), and that the role of environmental factors seems to be the most important for winter decomposition in cold biomes (Taylor and Jones 1990; Hobbie and Chapin III 1996).

The alpine forest-tundra transition from coniferous forests to shrublands and alpine meadows is sensitive to global climate change (Körner and Paulsen 2004). In such sensitive areas, different vegetations may give rise to dramatic variations in snow depth, snowmelt timing, soil temperature, and soil freezing depth, which, in combination, affect litter decomposition processes (Sjögersten and Wookey 2004; Xu et al. 2010). In addition, shifts in plant species along an elevational gradient could also be related to the availability of nutrients resulting from litter decomposition. In this study, we hypothesized that the litter decomposition of woody plants in an alpine foresttundra ecotone would increase with increasing elevation because of changes in temperature and the number of freeze-thaw cycles. To test this hypothesis, a short-term, wintertime, litter decomposition experiment was performed during one snow-covered season (from November 2012 to April 2013) in an alpine forest-tundra ecotone located on the eastern Tibetan Plateau, China. The objective of this study was to understand how the foliar litter decomposition of woody plants changes with elevation across an alpine forest-tundra ecotone over one winter season.

\section{Materials and methods}

\section{Site description}

This study was conducted on Zhegu Mountain $\left(31^{\circ} 51^{\prime} 428^{\prime \prime} \mathrm{N}, \quad 102^{\circ} 41^{\prime} 230^{\prime \prime} \mathrm{E}\right.$, at approximately 3200-4800 $\mathrm{m}$ above sea level (a.s.1.), with a remarkable vertical zonality), which is located in Li County, Sichuan, southwest China. This region is within a transitional area between the Tibetan Plateau and the Sichuan Basin, where the watersheds of the Dadu River and Minjiang River are distributed. There are mixed coniferous broadleaved forests, dark coniferous forests, alpine shrub woodlands, successive alpine meadows from the valley to the ridge, and a snow belt above $4500 \mathrm{~m}$ a.s.l. The weather is cool in summer and cold in winter. The annual mean air temperature ranges from approximately $6-12{ }^{\circ} \mathrm{C}$. The coldest month is January $\left(-8{ }^{\circ} \mathrm{C}\right)$, and the warmest month is July $\left(12.6{ }^{\circ} \mathrm{C}\right)$. The mean annual precipitation ranges from 600 to $1100 \mathrm{~mm}$. The snow-covered season starts in November and lasts until the end of April (about 6 or 7 months) in the alpine zone.

Three 50-m wide transects, which were separated by more than $1 \mathrm{~km}$, were set perpendicularly to the contour line in the forest-tundra ecotone. Vegetation types in these three transects, in which permanent sample plots were established in 2008, vary from a coniferous forest (3900-4000 m a.s.l.) to an alpine shrubland (4000-4200 m a.s.l.) to an alpine meadow (>4200 m a.s.1.). The dominant plant species in the coniferous forest are Minjiang fir (Abies faxoniana) and alpine rhododendron (Rhododendron taliense). The forest understory environment is cold and wet, with thick moss and humus layers. The woody shrub coverage and height decrease from the shrubland to the meadow. The shrubland is characterized primarily 
by vegetation consisting of some woody shrub species and long-lived perennial herbaceous plants. The dominant shrub species are Berberis silva-taroucana Schneid., Dasiphora fruticosa, Lonicera lanceolata, L. Myrtillus, Rosa omeiensis Rolfe, R. taliense Franch., and Sorbus rufopilosa. The major herbaceous plants are Aconitum fangianum, Agrostis hugoniana Rendle, Delphinium caeruleum, Deyeuxia scabrescens, Festuca wallichanica, Gentiana nubigena, Pedicularis davidii, Polygonum sphaerostachyum, and Senecio winklerianus. Sunlight increases from the coniferous forest to the shrubland and the alpine meadow, whereas the ground cover thickness decreases gradually. Soils are Cryumbreps and Histosols (United States Department of Agriculture Soil Taxonomy) in the coniferous forest and shrubland, and the alpine meadow, respectively. The alpine tree line, which is located around the upper elevational boundary of the coniferous forest, is approximately $4000 \mathrm{~m}$ a.s.l.

\section{Experimental design}

In October 2012, fresh, senescent foliage of deciduous plants was collected from the floor, and old foliage of evergreen plants was directly collected in vivo. Representative woody species in the ecotone-included conifer species (A. faxoniana), a broadleaved tree species (B. albosinensis), an evergreen shrub ( $R$. taliense), and deciduous shrubs ( $L$. lanceolate, $L$. myrtillus, and $S$. rufopilosa), all of which are native woody species. The litterbag technique was used to quantify the leaf litter decomposition rate. Air-dried leaf litter samples $(10 \mathrm{~g})$ were placed in $20 \times 20 \mathrm{~cm}^{2}$ litterbags with a $1 \mathrm{~mm}$ nylon net mesh at the upper side and $0.5 \mathrm{~mm}$ mesh at the bottom side to prevent needles from falling out (Cornelissen 1996). All litter in the litterbag was spread as flat as possible to keep it in contact with the soil. Each litterbag was labeled with an aluminum number tag. Chemical analyses of the initial litter were based on the oven-dried mass at $65{ }^{\circ} \mathrm{C}$ (see Table 1 for relevant data).

Three elevational transects in the forest-tundra ecotone were chosen as a grouping factor, and five litterbags for six litter species were placed along each transect at every elevation. A total of 270 litterbags (three transects $\times$ six species $\times$ five litterbags $\times$ three elevations) were placed at the site on November 23, 2012, and collected on May 6, 2013, at the end of the snow-covered season. Button temperature loggers
(iButton DS1921, Maxim/Dallas Semiconductor, Sunnyvale, CA, USA) were wrapped in plastic to protect them from water, and they were placed inside the litterbags to automatically monitor the temperature every $3 \mathrm{~h}$. The thickness of the snow cover at each elevation was measured from 15 fixed monitoring points at the end of each month (Fig. 1). We calculated average temperature, positive accumulated temperature, negative accumulated temperature, and soil freeze-thaw cycles throughout the entire experiment (Table 2).

Chemical analyses

Surface debris was removed from the collected litterbags, and then the litter inside was oven-dried at $65{ }^{\circ} \mathrm{C}$ to a constant weight. After weighing, all of the samples were ground and milled, and their chemical composition was analyzed. The ash-free dry weight was determined after the combustion of subsamples at $550{ }^{\circ} \mathrm{C}$ for $4 \mathrm{~h}$. Then, the samples were placed in a muffle furnace for $4 \mathrm{~h}$ at $550-600{ }^{\circ} \mathrm{C}$ (Allen et al. 1974). The $C$ content was determined using the dichromate oxidation ferrous sulfate titration method, and the nitrogen $(\mathrm{N})$ and phosphorus $(\mathrm{P})$ contents were determined by the Kjeldahl method and molybdenumblue colorimetry, respectively; lignin and cellulose contents were measured using the acid detergent lignin method (Graécas et al. 2005). All analyses were conducted in triplicate.

Calculations of litter dry mass loss $\left(L_{\mathrm{i}}\right)$ and the release $\left(R_{i}\right)$ of $\mathrm{C}, \mathrm{N}$, and $\mathrm{P}$, as well as the degradation of lignin and cellulose at the end of the snow-covered season, were determined as follows:

$L_{i}(\%)=100 \times \frac{\left(M_{\mathrm{o}}-M_{i}\right)}{M_{\mathrm{o}}}$
$R_{i}(\%)=100 \times \frac{\left(M_{\mathrm{o}} C_{\mathrm{o}}-M_{i} C_{i}\right)}{M_{\mathrm{o}} C_{\mathrm{o}}}$

where $M_{O}$ and $M_{i}$ are the dry mass of the initial and remaining litter in the litterbags, respectively; $C_{0}$ and $C_{i}$ are the concentrations $(\mathrm{mg} / \mathrm{g})$ of $\mathrm{C}, \mathrm{N}, \mathrm{P}$, lignin, or cellulose in the initial and remaining litter, respectively.

Statistical analyses

Data $(n=15)$ were subjected to analysis of variance (ANOVA), and significant differences among 
Table 1 Initial quality of foliar litter of representative woody plants at the alpine forest-tundra ecotone

\begin{tabular}{lllllll}
\hline Compound $(\mathrm{g} / \mathrm{kg})$ & L. myrtillus & R. taliense & L. lanceolata & B. albosinensis & S. rufopilosa & A. faxoniana \\
\hline Ash-free & $910.4(5.3)$ & $964.5(3.0)$ & $911.3(4.6)$ & $948.3(3.2)$ & $931.9(1.1)$ & $953.8(5.4)$ \\
Carbon & $499.9(41.2)$ & $574.6(31.5)$ & $534.8(32.5)$ & $534.7(40.2)$ & $528.6(35.6)$ & $568.3(26.2)$ \\
Nitrogen & $5.03(0.28)$ & $2.56(0.52)$ & $6.67(0.18)$ & $5.38(0.12)$ & $6.25(0.27)$ & $4.31(0.65)$ \\
Phosphorus & $3.21(0.08)$ & $0.53(0.11)$ & $2.93(0.08)$ & $0.73(0.07)$ & $1.54(0.12)$ & $1.09(0.06)$ \\
Lignin & $309.1(10.3)$ & $335.3(17.6)$ & $142.3(37.1)$ & $322.6(9.4)$ & $179.5(23.0)$ & $219.5(8.2)$ \\
Cellulose & $146.2(9.4)$ & $153.3(16.7)$ & $130.6(8.5)$ & $132.5(14.7)$ & $120.8(19.6)$ & $149.49(3.9)$ \\
C:N & 99.4 & 224.1 & 80.2 & 99.5 & 84.6 & 131.7 \\
Lignin:N & 61.5 & 130.8 & 21.3 & 60 & 28.7 & 50.9 \\
\hline
\end{tabular}

Data are expressed as means (SE) of ash-free, C, N, P, lignin, cellulose and C-to-N and lignin-to-N ratios $n=15$

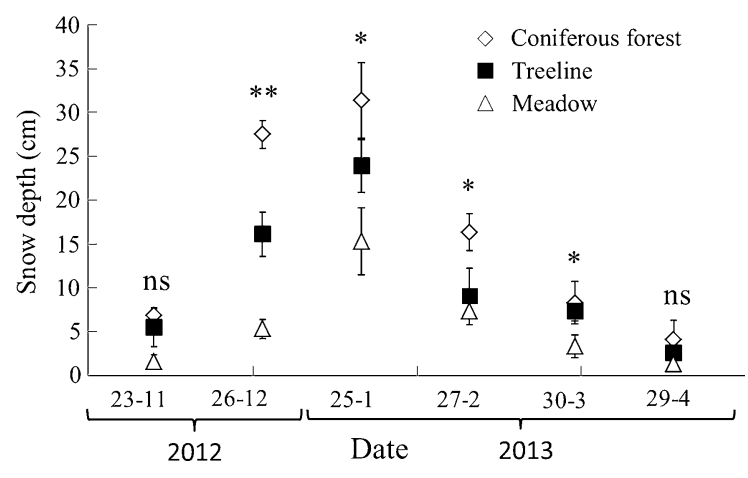

Fig. 1 Snow cover depth in the coniferous forest, at the treeline and in the meadow of the alpine forest-tundra ecotone during the snow-covered season (asterisk or double asterisks indicate significant differences among ecosystems at $P<0.05$ or 0.01 ; $n s$ not significant)

elevations were compared with Tukey's honestly significant difference test at $P=0.05$. To test for a correlation between mass loss and initial litter quality, we used Pearson's correlation coefficient test at the 0.05 level. The effects of elevation, species, and their interaction on the measured variables were tested by two-way ANOVA. All of the above analyses were conducted using SPSS for Windows v. 16.0 (SPSS Inc., Chicago, IL, USA).

\section{Results}

Snow accumulation and temperature dynamics

From December to March, there were significant differences in snow depth among the three ecosystems in the order of coniferous forest $>$ tree line $>$ meadow, but there were no significant differences in November (the start of snow cover formation) and April (the start of snowmelt) (Fig. 1). The snow depth under the forest was the greatest $(>30 \mathrm{~cm})$ in January 2013. The average daily temperature during litter decomposition was $-0.4{ }^{\circ} \mathrm{C}$ in the meadow, $-1.9^{\circ} \mathrm{C}$ at the tree line, and $-3.2{ }^{\circ} \mathrm{C}$ in the coniferous forest. Table 2 shows that the positive accumulated temperature was the highest at the tree line $\left(244.9^{\circ} \mathrm{C}\right)$, lower in the meadow $\left(148.3{ }^{\circ} \mathrm{C}\right)$, and lowest in the coniferous forest $\left(26.7^{\circ} \mathrm{C}\right)$, whereas the negative accumulated

Table 2 Topographical and environment factors of forest, treeline, and meadow sites at the alpine forest-tundra ecotone of litter decomposition during the snow-covered season

\begin{tabular}{lllllll}
\hline Plant community & $\begin{array}{l}\text { Altitude } \\
(\mathrm{m})\end{array}$ & $\begin{array}{l}\text { Slope } \\
\left({ }^{\circ}\right)\end{array}$ & $\begin{array}{l}\text { Average } \\
\text { temperature }\left({ }^{\circ} \mathrm{C}\right)\end{array}$ & $\begin{array}{l}\text { +ve Sum } \\
\text { temp }\left({ }^{\circ} \mathrm{C}\right)\end{array}$ & $\begin{array}{l}\text {-ve Sum } \\
\text { temp }\left({ }^{\circ} \mathrm{C}\right)\end{array}$ & $\begin{array}{l}\text { Freeze-thaw } \\
\text { cycles } \\
(\text { number })\end{array}$ \\
\hline Alpine meadow & 4200 & 34 & -0.4 & 148.3 & -214.9 & 327 \\
Treeline & 4000 & 34 & -1.9 & 244.9 & -492.9 & 270 \\
Coniferous forest & 3900 & 32 & -3.2 & 26.7 & -547.3 & 135 \\
\hline
\end{tabular}

ave temp. Average temperature, +ve sum temp positive accumulated temperature, -ve sum temp negative accumulated temperature 
temperature was the highest in the forest $\left(-547.3{ }^{\circ} \mathrm{C}\right)$. The number of freeze-thaw cycles in the meadow was 327, which was far greater than those in the forest (135) and at the tree line (270), indicating that intensive temperature variations occurred in the meadow.

\section{Mass loss}

The litter mass loss rates of L. lanceolata, S. rufopi$l o s a$, and $A$. faxoniana varied significantly $(P<0.01)$ with elevation (Fig. 2), and higher mass loss was observed in the meadow than in the forest or at the tree line. However, the mass loss rates of the remaining species did not vary significantly with elevation. Plant species had a significant influence on the litter mass loss $(F=64.68, P<0.001$, Table 3$)$, and the ash-free dry weight loss rates were in the order of L. lanceolata $(27 \%)>$ L. myrtillus $(18 \%)>$ S. rufopilosa $(16 \%)$ $>$ B. albosinensis $(12 \%)>A$. faxoniana $(6 \%)>R$. taliense (5\%). Two-way ANOVA showed that plant species, elevation, and their interaction had significant effects on the mass loss and ash-free dry weight loss $(P<0.001)$ for all litters (Fig. 2; Table 3).

\section{Litter chemistry and substrate quality}

The C content of the litters of all woody species generally decreased at the end of the snow-covered season, whereas the lignin content increased in almost all of the litters, except L. myrtillus. Changes in the N, $\mathrm{P}$, and cellulose contents varied with species. The $\mathrm{C} / \mathrm{N}$ ratio increased in $R$. taliense, but decreased in other species. In contrast, the lignin/ $\mathrm{N}$ ratio decreased in $L$. myrtillus and B. albosinensis, but increased in the remaining species. There were significant speciesspecific impacts on the litter chemical characteristics $(P<0.001)$. Meanwhile, elevation also significantly impacted the $\mathrm{N}, \mathrm{P}$, cellulose, and lignin contents $(P \leq 0.01)$, but not the $\mathrm{C}$ content or the $\mathrm{C} / \mathrm{N}$ and lignin/ $\mathrm{N}$ ratios $(P>0.05)$ (Table 3$)$. In addition to the $\mathrm{C} / \mathrm{N}$ ratio, the interaction of plant species and elevation had a significant effect on litter quality $(P<0.001)$. We examined the relationship between the initial litter substrate quality and the mass loss rate in the alpine forest-tundra ecotone (Table 4), and we found that all $\mathrm{C}$ fractions, including total $\mathrm{C}$, cellulose, lignin content, and $\mathrm{C} / \mathrm{N}$ and lignin/ $\mathrm{N}$ ratios, were negatively correlated with mass loss, while the $\mathrm{N}$ and
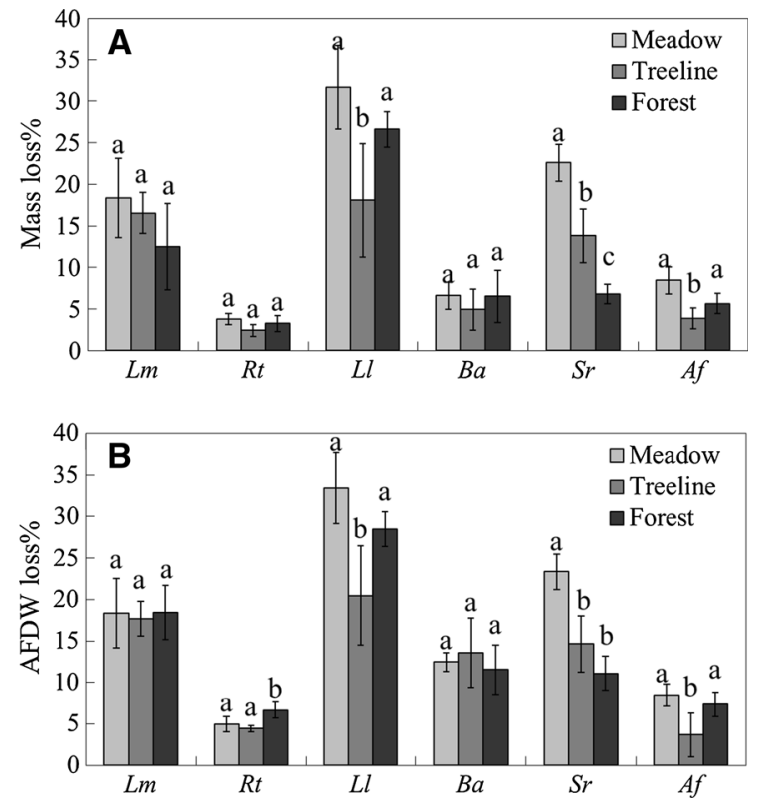

Fig. 2 Mass loss rate (a) and ash-free dry weight (AFDW) loss rate (b) of the foliar litter in the alpine forest-tundra ecotone over the snow-covered season. Af A. faxoniana; $B a B$. albosinensis; Ll L. lanceolate; Lm L. myrtillus; Sr S. rufopilosa; Rt $R$. taliense. Treatments with the same letter are not significantly different from each other at $P<0.05$. Data are mean $\pm \mathrm{SE}, n=15$

P contents were significantly positively correlated with mass loss $(P<0.01)$.

$\mathrm{C}, \mathrm{N}$, and $\mathrm{P}$ release, and lignin and cellulose degradation

The release of $\mathrm{C}, \mathrm{N}$, and $\mathrm{P}$ from plant litter significantly increased with increasing elevation, especially for $S$. rufopilosa (Fig. 3). In addition, C release from A. faxoniana, B. albosinensis, and $S$. rufopilosa, $\mathrm{N}$ release from A. faxoniana and $S$. rufopilosa, P release from L. myrtillus, L. lanceolata, and $S$. rufopilosa, cellulose degradation in S. rufopilosa, B. albosinensis, and $R$. taliense, and lignin degradation in L. myrtillus significantly increased with increasing elevation.

Litter $\mathrm{C}$ was released by all species during the decomposition process; litter $\mathrm{N}$ showed a net release only from $R$. taliense ( $21 \%$ ), while it increased in the remaining species; $\mathrm{P}$ showed a net release from $L$. myrtillus (44\%), L. lanceolata (46\%), and A. faxoniana (15\%), while it increased in S. rufopilosa, $B$. 
Table 3 Effects of altitude (A) and species (S), and their interaction on litter mass loss, concentrations and release rates of carbon, nitrogen, phosphorus, cellulose and lignin in foliar litter of the representative woody plants at the alpine forest-tundra ecotone over the snow-covered season

\begin{tabular}{|c|c|c|c|c|}
\hline & Source & $d f$ & $F$ & $P$-level \\
\hline \multirow[t]{3}{*}{ Carbon concentration $(\mathrm{g} / \mathrm{kg})$} & $\mathrm{S}$ & 5 & 14.43 & $<0.001$ \\
\hline & A & 2 & 0.768 & 0.467 \\
\hline & $\mathrm{S}^{*} \mathrm{~A}$ & 10 & 4.203 & $<0.001$ \\
\hline \multirow[t]{3}{*}{ Nitrogen concentration $(\mathrm{g} / \mathrm{kg})$} & $\mathrm{S}$ & 5 & 321.511 & $<0.001$ \\
\hline & A & 2 & 6.637 & 0.002 \\
\hline & $\mathrm{S}^{*} \mathrm{~A}$ & 10 & 3.898 & $<0.001$ \\
\hline \multirow[t]{3}{*}{ Phosphorus concentration $(\mathrm{g} / \mathrm{kg})$} & S & 5 & 39.489 & $<0.001$ \\
\hline & A & 2 & 11.835 & $<0.001$ \\
\hline & $\mathrm{S}^{*} \mathrm{~A}$ & 10 & 19.874 & $<0.001$ \\
\hline \multirow[t]{3}{*}{ Cellulose concentration $(\mathrm{g} / \mathrm{kg})$} & S & 5 & 7.426 & $<0.001$ \\
\hline & A & 2 & 10.11 & $<0.001$ \\
\hline & $\mathrm{S}^{*} \mathrm{~A}$ & 10 & 4.228 & $<0.001$ \\
\hline \multirow[t]{3}{*}{ Lignin concentration $(\mathrm{g} / \mathrm{kg})$} & S & 5 & 39.652 & $<0.001$ \\
\hline & A & 2 & 4.829 & 0.01 \\
\hline & $\mathrm{S}^{*} \mathrm{~A}$ & 10 & 7.438 & $<0.001$ \\
\hline \multirow[t]{3}{*}{$\mathrm{C}: \mathrm{N}$} & S & 5 & 286.095 & $<0.001$ \\
\hline & A & 2 & 0.413 & 0.663 \\
\hline & $\mathrm{S}^{*} \mathrm{~A}$ & 10 & 1.793 & 0.077 \\
\hline \multirow[t]{3}{*}{$\mathrm{C}: \mathrm{P}$} & S & 5 & 102.727 & $<0.001$ \\
\hline & A & 2 & 1.273 & 0.286 \\
\hline & $\mathrm{S}^{*} \mathrm{~A}$ & 10 & 4.426 & $<0.001$ \\
\hline \multirow[t]{3}{*}{ Mass loss $(\%)$} & S & 5 & 64.676 & $<0.001$ \\
\hline & A & 2 & 19.715 & $<0.001$ \\
\hline & $\mathrm{S}^{*} \mathrm{~A}$ & 10 & 8.721 & $<0.001$ \\
\hline \multirow[t]{3}{*}{ Ash-free dry weight loss (\%) } & S & 5 & 68.241 & $<0.001$ \\
\hline & A & 2 & 10.286 & $<0.001$ \\
\hline & $\mathrm{S}^{*} \mathrm{~A}$ & 10 & 7.18 & $<0.001$ \\
\hline \multirow[t]{3}{*}{ Carbon release $(\%)$} & S & 5 & 19.196 & $<0.001$ \\
\hline & A & 2 & 3.034 & 0.054 \\
\hline & $\mathrm{S}^{*} \mathrm{~A}$ & 10 & 2.787 & 0.006 \\
\hline \multirow[t]{3}{*}{ Nitrogen release $(\%)$} & S & 5 & 16.138 & $<0.001$ \\
\hline & A & 2 & 7.144 & 0.001 \\
\hline & $\mathrm{S}^{*} \mathrm{~A}$ & 10 & 5.286 & $<0.001$ \\
\hline \multirow[t]{3}{*}{ Phosphorus release $(\%)$} & S & 5 & 9.219 & $<0.001$ \\
\hline & A & 2 & 5.473 & 0.006 \\
\hline & $\mathrm{S} * \mathrm{~A}$ & 10 & 20.188 & $<0.001$ \\
\hline \multirow[t]{3}{*}{ Cellulose degradation $(\%)$} & S & 5 & 13.66 & $<0.001$ \\
\hline & A & 2 & 10.963 & $<0.001$ \\
\hline & $\mathrm{S}^{*} \mathrm{~A}$ & 10 & 5.487 & $<0.001$ \\
\hline \multirow[t]{3}{*}{ Lignin degradation (\%) } & S & 5 & 40.415 & $<0.001$ \\
\hline & A & 2 & 1.123 & 0.33 \\
\hline & $\mathrm{S}^{*} \mathrm{~A}$ & 10 & 7.65 & $<0.001$ \\
\hline
\end{tabular}

(40\%) and $R$. taliense (36\%) than in the other species. The lignin content increased by 33, 15, 14, and $7 \%$ in L. lanceolata, R. taliense, S. rufopilosa, 
Table 4 Pearson correlations between the initial litter substrate quality and mass loss in the forest, at the treeline and in the meadow of the alpine forest-tundra ecotone

\begin{tabular}{|c|c|c|c|c|c|c|c|}
\hline Ecosystem & Carbon & Nitrogen & Phosphorus & Cellulose & Lignin & $\mathrm{C}: \mathrm{N}$ & Lignin: $\mathrm{N}$ \\
\hline Alpine meadow & -0.34 & $0.764^{* *}$ & $0.767^{* *}$ & $-0.562^{* *}$ & $-0.738^{* *}$ & $-0.646^{* *}$ & $-0.706^{* *}$ \\
\hline Treeline & $-0.362^{*}$ & $0.612^{* *}$ & $0.845^{* *}$ & $-0.532^{* *}$ & $-0.448^{*}$ & $-0.551^{* *}$ & $-0.518^{* *}$ \\
\hline Coniferous forest & -0.224 & $0.594^{* *}$ & $0.770^{* *}$ & -0.251 & $-0.540^{* *}$ & $-0.488^{* *}$ & $-0.521^{* *}$ \\
\hline
\end{tabular}

$n=15$

${ }^{*} P<0.05,{ }^{* *} P<0.01$

and A. faxoniana, respectively, whereas it decreased by $32 \%$ in L. myrtillus.

Two-way ANOVA showed that elevation had significant effects on $\mathrm{N}$ and $\mathrm{P}$ release, as well as cellulose degradation $(P<0.01)$, but not on $\mathrm{C}$ release and lignin degradation $(P>0.05)$ (Table 3$)$. Plant species had significant effects on $\mathrm{C}, \mathrm{N}$, and $\mathrm{P}$ release, as well as lignin and cellulose degradation
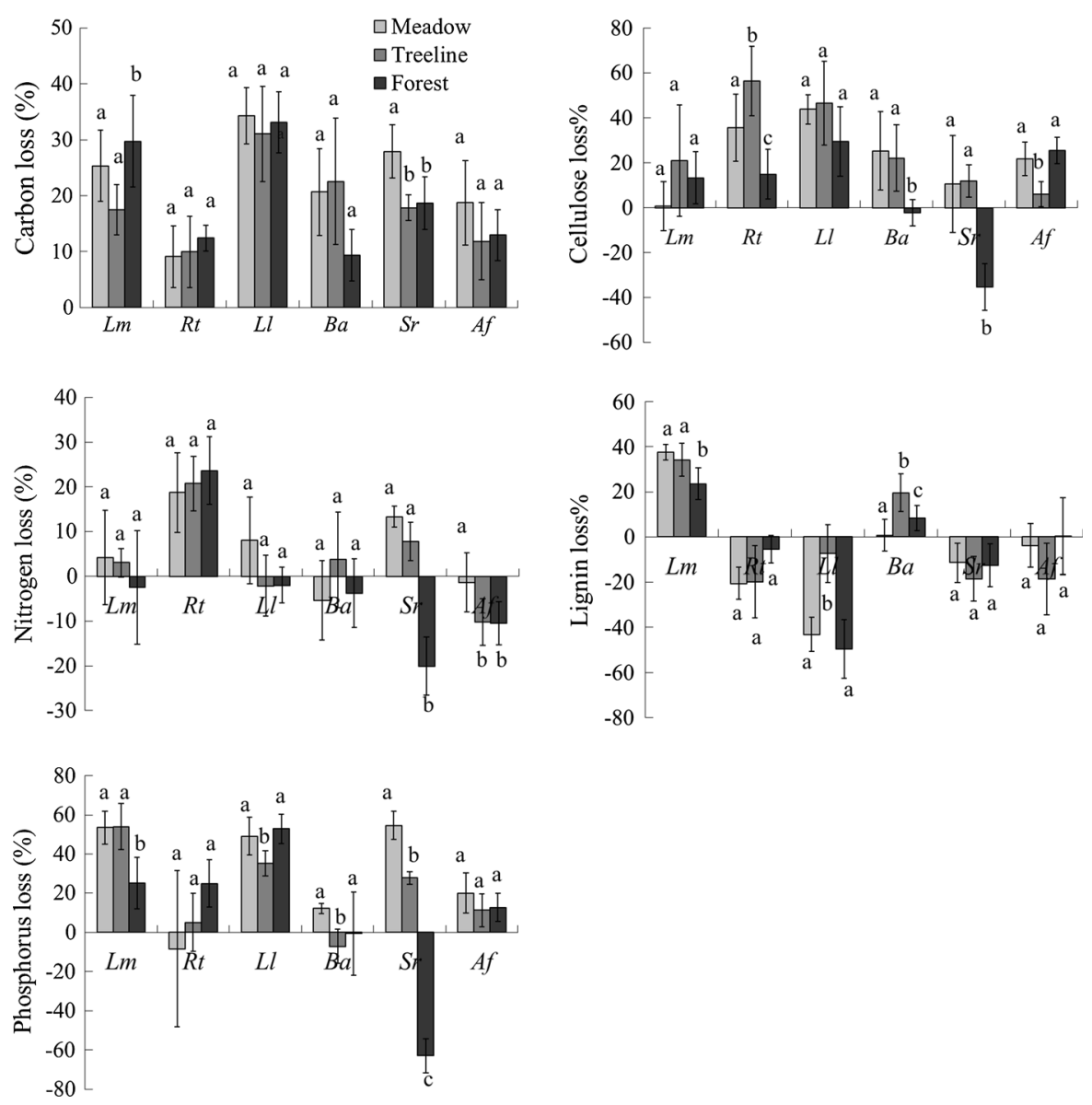

Fig. 3 Release rate of carbon, nitrogen, phosphorus, lignin and cellulose in representative woody species leaf litter at the alpine forest-tundra ecotone over the snow-covered season. Af $A$. faxoniana; Ba B. albosinensis; Ll L. lanceolate; Lm L. myrtillus;

Sr S. rufopilosa; Rt R. taliense. Treatments with the same letter are not significantly different from each other at $P<0.05$. Data are mean $\pm \mathrm{SE}, n=15$ 
$(P<0.001)$. Meanwhile, the interaction between species and elevation also had a significant effect on the litter chemical composition $(P<0.01)$.

\section{Discussion}

Our findings support the idea that the litter decomposition of some woody species will change significantly with elevation across the alpine forest-tundra ecotone. Litter mass loss was affected by elevation, but such effects differed among plant species, as evidenced by the generally faster decomposition of $A$. faxoniana, $L$. lanceolata, and S. rufopilosa in the meadow than in the forest or at the tree line. However, the rate of ash-free dry weight loss of $R$. taliense was generally slower at the tree line and in the meadow than in the forest. Studies have shown that litter decomposition rates are closely correlated with environmental parameters, such as temperature and moisture (Aerts 2006; Baptist et al. 2010). Although the alpine meadow is located at a higher elevation than the coniferous forest, its average daily temperature was higher because of a temperature inversion phenomenon. The temperature and snow-covered gradients generated different vegetation types that, in turn, controlled the decomposition of organic matter. Indeed, an earlier snowmelt date and a lower snow depth were observed in the alpine meadow, followed by those at the tree line and in the forest. The average decomposition temperature in the alpine meadow was 2.73 and $1.53{ }^{\circ} \mathrm{C}$ higher than those of the coniferous forest and at the tree line, respectively (Table 2), which would accelerate litter decomposition under future alpine climate warming scenarios, particularly during the winter season.

The solar radiation intensity increased from the coniferous forest to the alpine meadow, while the plant height and crown density decreased, resulting in an increase in surface evaporation and a reduction in soil surface moisture. In addition, a previous study of the same site proved that ground cover (moss and litter layers) decreases with elevation, and the maximal water-holding capacity of litter is significantly higher in the coniferous forest than at the tree line and in the meadow (Liu et al. 2011). However, more studies are needed to characterize the comprehensive decomposition pattern, because the effect of soil biota on litter decomposition was not examined in the present study. The soil microbial community that drives litter decomposition may also vary among these three elevations and their different soil and vegetation types, which also warrants further studies. However, if plant species shift their ranges, not only will litter decomposition be altered as a result of changes in snow cover and temperature, but the presence of other plants at the new elevation may also influence the abiotic environment, and thus the decomposer community. Indeed, the decomposition of woody species in response to climate warming is complicated in alpine ecosystems.

Our research also showed that an upward elevational shift would accelerate the release of $\mathrm{C}$ and nutrients from litter, especially for $S$. rufopilosa, as the rate of C release from $S$. rufopilosa was higher in the meadow than that in the forest or at the tree line. In addition, while there was a net accumulation of $\mathrm{N}, \mathrm{P}$, and cellulose in the forest, there was a net release of these constituents in the meadow. $\mathrm{N}$ release from $A$. faxoniana, cellulose release from B. albosinensis, $R$. taliense, and $S$. rufopilosa, and lignin release from $L$. myrtillus increased significantly from the forest to the treeline or the meadow. The number of freeze-thaw cycles varied among the three, elevations and they were the highest in the alpine meadow, which might affect nutrient release by enhancing the physical degradation of litter components, especially relatively labile components such as dissolved organic carbon (Deng et al. 2014). The litter decomposition of some labile species, such as $S$. rufopilosa, might be easily influenced by the number of freeze-thaw cycles and temperature, compared with that of recalcitrant species, which is consistent with the results of Sjögersten and Wookey (2004).

We found $\mathrm{N}$ and $\mathrm{P}$ immobilization in the litter of some species at the end of the snow-covered season. Melting snow is a very likely source of $\mathrm{N}$ and $\mathrm{P}$, and birch leaves and some fir needles could assimilate $\mathrm{N}$ and $\mathrm{P}$ from the environment (Taylor and Jones 1990). $\mathrm{N}$ or $\mathrm{P}$ content increases because microbes immobilize $\mathrm{N}$ and $\mathrm{P}$ after plant senescence in the autumn, and, thus, the released $\mathrm{N}$ and $\mathrm{P}$ are retained throughout the winter (Lipson et al. 1999; Uchida et al. 2005). Studies have shown that vegetation and seasonality significantly influence the structure of the soil microbial community, as well as microbial biomass $\mathrm{C}$ and $\mathrm{N}$. For instance, soil microbial biomass $\mathrm{C}$ and $\mathrm{N}$ were higher in the alpine meadow than in the forest, whereas soil organic $\mathrm{C}$ increased with elevation and reached $78 \mathrm{mg} / \mathrm{g}$ in the alpine meadow (Liu et al. 2012). This 
possibly resulted because the decomposition rates of some species were higher in the meadow than in the forest and at the tree line. In addition, our research found that the lignin content increased, whereas the cellulose content decreased, in the litter of most woody species. In the short term, there might be a lag period before the loss of acid-unhydrolyzable residue (AUR), and there may even be a net gain in AUR, which reflects a possible conversion of soluble materials into more complex structures (Preston et al. 2009). Cellulose is an acid-hydrolyzable carbohydrate (ACID), and lignin is an AUR (Preston et al. 2009). Usually, ACIDs are released faster than AURs. For example, ACIDs decreased and AURs increased with increasing mass loss of Scots pine (Pinus sylvestris) needles during a 3-year decomposition period (Coūteaux et al. 1998).

Our results confirmed that the litter decomposition of three deciduous shrub species (L. myrtillus, L. lanceolata, and $S$. rufopilosa) was significantly faster than that of the other two tree species (A. faxoniana and $B$. albosinensis) and one evergreen shrub ( $R$. taliense). Thus, litter types with favorable chemical constituents could be rapidly decomposed in the early decomposition stage (Murphy et al. 1998; Fierer et al. 2005; Gavazov 2010). The litter traits of plant species are important factors that control the decomposition rate of organic matter in ecosystems (Cornelissen 1996; Cornwell et al. 2008). For example, needles, hardwood leaves, grass, and forbs showed different mass loss rates, 10.0, 15.6, 21.0, and $39.0 \%$, respectively, under snow cover in a balsam fir (A. balsamea) forest over a 6-month snow-covered season (Taylor and Jones 1990). Moreover, the decomposition rate of different plant types is generally in the order of forbs $>$ graminoids $>$ deciduous shrubs $>$ evergreen shrubs (Cornelissen 1996; Cornelissen et al. 2007). In general, our results are consistent with the above studies to some degree, as the litter of deciduous shrubs decomposed significantly faster than that of evergreen shrubs and trees. Because this study was restricted to woody species, the decompositions of herbs, mosses, lichens, and other ground cover species remain to be studied.

\section{Conclusions}

In conclusion, our study supports the idea that the observed differences in litter decomposition and nutrient release with elevation will also occur in the alpine forest-tundra ecotone over time because of a shift in woody plant composition under a changing climate, although such decomposition patterns differed among the tested woody species. In the long term, changes in the species composition of alpine plants will result in changes in the substrate quality and decomposability of litter; hence, this will alter the environment of plants that shift their ranges upward. Thus, further studies regarding how the combined effects of elevation and shifting plant ranges could alter litter decomposition and ecosystem sustainability are warranted.

Acknowledgments This research was financially supported by projects from the National Natural Science Foundation of China (31200345, 31570605), Ministry of Education Doctoral Fund Project (20115103120003), Sichuan Education Department Key Project (11ZA079), and Key Laboratory of Ecological Forestry Engineering of Sichuan Province. We confirmed that the field study did not involve endangered or protected species as per the field experiment approval by the Forestry Bureau of Western Sichuan in the Aba City, Sichuan, China. We thank Dedong Zhou from the Forestry Bureau of Western Sichuan and Tuowei Ji, Jianping Li, Xiaoyan Song, and other graduate students at the Institute of Ecology and Forestry, Sichuan Agricultural University, for their field assistances and laboratory analyses.

Open Access This article is distributed under the terms of the Creative Commons Attribution 4.0 International License (http:// creativecommons.org/licenses/by/4.0/), which permits unrestricted use, distribution, and reproduction in any medium, provided you give appropriate credit to the original author(s) and the source, provide a link to the Creative Commons license, and indicate if changes were made.

\section{References}

Aerts R (2006) The freezer defrosting: global warming and litter decomposition rates in cold biomes. J Ecol 94:713-724

Allen SE, Grimshaw H, Parkinson JA, Quarmby CL (1974) Chemical analysis of ecological materials. Blackwell, Boston

Baptist F, Yoccoz NG, Choler P (2010) Direct and indirect control by snow cover over decomposition in alpine tundra along a snowmelt gradient. Plant Soil 328:397-410

Berg B, McClaugherty C (2008) Plant litter: decomposition, humus formation, carbon sequestration. Springer, Berlin

Cornelissen J (1996) An experimental comparison of leaf decomposition rates in a wide range of temperate plant species and types. J Ecol 84:573-582

Cornelissen JHC, Van Bodegom PM, Aerts R, Callaghan TV, Van Logtestijn RSP, Alatalo J, Stuart Chapin F, Gerdol R, Gudmundsson J, Gwynn-Jones D (2007) Global negative 
vegetation feedback to climate warming responses of leaf litter decomposition rates in cold biomes. Ecol Lett 10:619-627

Cornwell WK, Cornelissen JH, Amatangelo K, Dorrepaal E, Eviner VT, Godoy O, Hobbie SE, Hoorens B, Kurokawa H, Pérez-Harguindeguy N (2008) Plant species traits are the predominant control on litter decomposition rates within biomes worldwide. Ecol Lett 11:1065-1071

Coūteaux M, McTiernan K, Berg B, Szuberla D, Dardenne P, Bottner P (1998) Chemical composition and carbon mineralisation potential of Scots pine needles at different stages of decomposition. Soil Biol Biochem 30:583-595

Deng CC, Chen YM, He RL, Liu Y, Zhang J (2014) Leaching of dissolved organic carbon from decomposing litter during the snow cover period at an alpine timberline ectone in western Sichuan, China. Chin J Ecol 33:2921-2929

Fierer N, Craine JM, McLauchlan K, Schimel JP (2005) Litter quality and the temperature sensitivity of decomposition. Ecology 86:320-326

Gavazov KS (2010) Dynamics of alpine plant litter decomposition in a changing climate. Plant Soil 337:19-32

Grace J, Berninger F, Nagy L (2002) Impacts of climate change on the tree line. Ann Bot 90:537-544

Graécas MA, Bèarlocher F, Gessner MO (2005) Methods to study litter decomposition: a practical guide. Springer, Dordrecht

Hobbie SE, Chapin FS III (1996) Winter regulation of tundra litter carbon and nitrogen dynamics. Biogeochemistry 35:327-338

Körner C, Paulsen J (2004) A world-wide study of high altitude treeline temperatures. J Biogeogr 31:713-732

Lenoir J, Gegout J, Marquet P, de Ruffray P, Brisse H (2008) A significant upward shift in plant species optimum elevation during the 20th century. Science 320:1768-1771

Lipson DA, Schmidt SK, Monson RK (1999) Links between microbial population dynamics and nitrogen availability in an alpine ecosystem. Ecology 80:1623-1631

Liu Y, Zhang J, Yang WQ, Wu FZ, Huang X, Yan BG (2011) Ground coverage and soil hydrological action of alpine timberline ecotone in western Sichuan. Scientia silvae sinicae 47:1-6

Liu Y, Zhang J, Yan BG, Huang X, Xu ZF, Wu FZ (2012) Seasonal dynamics in soil microbial biomass carbon and nitrogen and microbial quantity in a forest-alpine tundra ecotone, eastern Qinghai-Tibetan Plateau, China. Chin J Plant Ecol 36:382-392

Murphy KL, Klopatek JM, Klopatek CC (1998) The effects of litter quality and climate on decomposition along an elevational gradient. Ecol Appl 8:1061-1071

Pauli H, Gottfried M, Reiter K, Klettner C, Grabherr G (2007) Signals of range expansions and contractions of vascular plants in the high Alps: observations (1994-2004) at the GLORIA master site Schrankogel, Tyrol, Austria. Glob Change Biol 13:147-156

Preston CM, Nault JR, Trofymow J, Smyth C (2009) Chemical changes during 6 years of decomposition of 11 litters in some Canadian forest sites. Part 1. Elemental composition, tannins, phenolics, and proximate fractions. Ecosystems 12:1053-1077

Santonja M, Baldy V, Fernandez C, Balesdent J, Gauquelin T (2015) Potential shift in plant communities with climate change: outcome on litter decomposition and nutrient release in a Mediterranean Oak forest. Ecosystems 18:1253-1268

Sjögersten S, Wookey PA (2004) Decomposition of mountain birch leaf litter at the forest-tundra ecotone in the Fennoscandian mountains in relation to climate and soil conditions. Plant Soil 262:215-227

Stocker T, Qin D, Plattner G, Tignor M, Allen S, Boschung J, Nauels A, Xia Y, Bex B, Midgley B (2013). IPCC, 2013: climate change 2013: the physical science basis. Contribution of working group I to the fifth assessment report of the intergovernmental panel on climate change

Sturm M, Schimel J, Michaelson G, Welker JM, Oberbauer SF, Liston GE, Fahnestock J, Romanovsky VE (2005) Winter biological processes could help convert arctic tundra to shrubland. Bioscience 55:17-26

Taylor BR, Jones HG (1990) Litter decomposition under snow cover in a Balsam Fir Forest. Can J Bot 68:112-120

Theurillat JP, Guisan A (2001) Potential impact of climate change on vegetation in the European Alps: a review. Clim Chang 50:77-109

Uchida M, Mo W, Nakatsubo T, Tsuchiya Y, Horikoshi T, Koizumi H (2005) Microbial activity and litter decomposition under snow cover in a cool-temperate broad-leaved deciduous forest. Agric For Meteorol 134:102-109

Wipf S, Rixen C (2010) A review of snow manipulation experiments in arctic and alpine tundra ecosystems. Polar Res 29:95-109

Wu FZ, Yang WQ, Zhang J, Deng R (2010) Litter decomposition in two subalpine forests during the freeze-thaw season. Acta Oecol 36:135-140

Xu GP, Hu YG, Wang SP, Zhang ZH, Chang XF, Duan JC, Luo CY, Chao ZG, Su AL, Lin QY (2010) Effects of litter quality and climate change along an elevation gradient on litter mass loss in an alpine meadow ecosystem on the Tibetan plateau. Plant Ecol 209:257-268

Zhu JX, He XH, Wu FZ, Yang WQ, Tan B (2012) Decomposition of Abies faxoniana litter varies with freeze-thaw stages and altitudes in subalpine/alpine forests of southwest China. Scand J For Res 27:586-596 